\title{
24. SEDIMENTARY STRUCTURES OF FINE-GRAINED SEDIMENTS FROM THE MISSISSIPPI FAN: THIN-SECTION ANALYSIS 1
}

\author{
Michel Cremer, Université de Bordeaux \\ and \\ Dorrik A. V. Stow, Nottingham University ${ }^{2}$
}

\begin{abstract}
Four major lithologic facies were recovered from the Mississippi Fan during Deep Sea Drilling Project (DSDP) Leg 96. These are (1) sand and silt, (2) silt-laminated mud, (3) silty mud, and (4) mud and clay. About 50 thin sections were prepared from selected samples of the fine-grained sediments using freeze-drying and impregnation techniques. The thin sections were examined in detail for their microscopic sedimentary structures and associated grain-size variations. The principal primary and secondary structures are (1) homogeneous bedding, (2) composite bedding, (3) graded bedding, (4) parallel lamination, (5) cross-lamination, (6) discontinuous and irregular structures, and (7) microfaults and loading structures. Most of these structures, and their common occurrence in regular vertical successions over 5 to $>100 \mathrm{~cm}$, can be interpreted in terms of the standard sequences for fine-grained turbidites. However, several structures are less readily interpreted, including: (1) thin, dark mud laminae, (2) reverse-graded silt laminae, (3) irregularly interlayered mud and silt, and (4) isolated mud lenses in massive silts. We suggest that these structures are most likely the result of particularly rapid deposition from large muddy turbidity currents onto a soft, unconsolidated substrate.
\end{abstract}

\section{INTRODUCTION}

During DSDP Leg 96 in the Gulf of Mexico, we drilled at nine sites into or through the youngest depositional unit (fan lobe) of the Mississippi Fan (Fig. 1). This fan lobe (Bouma et al., 1983/84) extends about $600 \mathrm{~km}$ downslope from the Mississippi Canyon near the present Mississippi Delta out onto the Sigsbee and Florida abyssal plains.

The lithologies recovered at these fan sites consist mainly of terrigenous material, which was deposited very rapidly during the late Wisconsin glacial stage (site chapters, this volume). Clays, muds, and silts are the most abundant lithologies at all sites. Sands, with rare gravels and pebbly muds, form less than $15 \%$ of the midfan channel fill sections (Sites 620 and 621), whereas sands and fine silty sands form up to $50 \%$ of the lower fan deposits (Sites 614 and 615). Calcareous biogenic sediments are volumetrically of minor importance, occurring only as a thin postglacial Holocene cover at most sites and as a thicker Wisconsin debris flow deposit intercalated in the clastics on the lower fan (Site 615).

Based on their compositional, textural, and structural characteristics, these lithologies can be divided into eight sediment facies (Table 1) (Stow et al., this volume).

Most of the terrigenous facies are interpreted as deposits of mass gravity flow or resedimentation processes. This is primarily based on the high sedimentation rates, the absence of biogenic components and bioturbation, and the abundance of primary sedimentary structures indicative of deposition from turbidity currents,

\footnotetext{
${ }^{1}$ Bouma, A. H., Coleman, J. M., Meyer, A. W., et al., Init. Repts. DSDP, 96: Washington (U.S. Govt. Printing Office).

2 Addresses: (Cremer) Département de Géologie et Océanographie, Université de Bordeaux I, 33405 Talence, France; (Stow) Geology Department, Nottingham University, Nottingham, England.
}

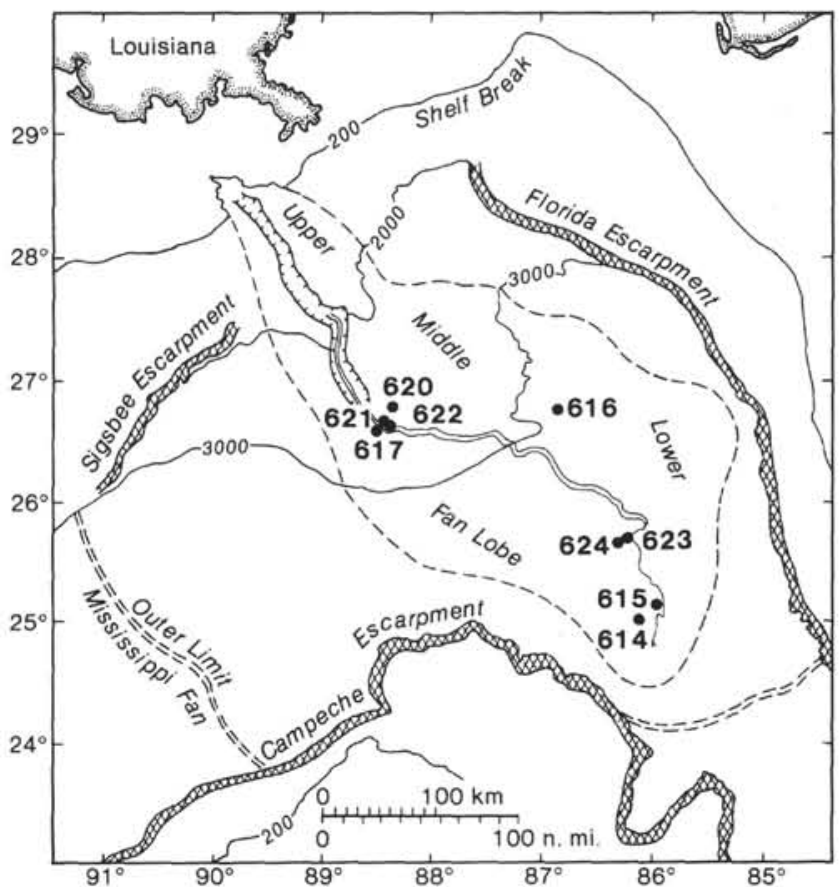

Figure 1. Mississippi Fan with location of DSDP Leg 96 sites.

debris flows, or sediment slides (Stow et al., this volume). Resedimentation took place during glacial low stands of sea level, partly as a consequence of the very high terrigenous input from the Mississippi River system onto the adjacent shelf and upper slope.

In this chapter we define the sedimentary structures in the finer-grained facies in more detail than is typically done during visual observation. We also attempt to more accurately infer the nature of the depositional mechanisms involved. In order to do this, vertically oriented samples were carefully removed from the cores and pre- 
Table 1. Main facies recovered at all sites on DSDP Leg 96 to the Mississippi Fan. ${ }^{\mathrm{a}}$

\begin{tabular}{|c|c|c|c|}
\hline Facies & Grain size & $\begin{array}{l}\text { Carbonate } \\
\text { percentage }\end{array}$ & Description \\
\hline Oozes and muddy oozes & $\begin{array}{l}\text { Mainly silt and clay } \\
\text { sized, and sand-sized } \\
\text { foraminifers }\end{array}$ & $\begin{array}{l}\text { Oozes } \\
\quad>75 \% \\
\text { Muddy oozes } \\
\quad>50 \%\end{array}$ & $\begin{array}{l}\text { Planktonic microfossils dominant, including foramini- } \\
\text { fers, nannofossils and siliceous microfossils; homo- } \\
\text { geneous, bioturbated }\end{array}$ \\
\hline Calcareous muds & $\begin{array}{l}\text { Mainly silt and clay } \\
\text { sized, some fine } \\
\text { sand-sized material }\end{array}$ & $10-50 \%$ & $\begin{array}{l}\text { Planktonic microfossils }<50 \% \text {, terrigenous component } \\
>50 \% \text {; homogeneous, bioturbated }\end{array}$ \\
\hline Clay and muds & $\begin{array}{l}60-90 \% \text { clay sized } \\
<0.5 \% \text { sand sized }\end{array}$ & $<10 \%$ & $\begin{array}{l}\text { Homogeneous thick intervals with diffuse silt patches } \\
\text { and muds with rare thin silt laminae and/or color- } \\
\text { banding }\end{array}$ \\
\hline $\begin{array}{l}\text { Silty muds and muddy } \\
\text { silts }\end{array}$ & $\begin{array}{l}10-60 \% \text { clay sized } \\
<5 \% \text { sand sized }\end{array}$ & $<10 \%$ & $\begin{array}{l}\text { Commonly in beds } 5-100 \mathrm{~cm} \text { thick; beds are either } \\
\text { structureless or indistinctly graded, or included } \\
\text { within a sand-mud graded unit }\end{array}$ \\
\hline Silt-laminated muds & $\begin{array}{l}5-70 \% \text { clay sized } \\
20-80 \% \text { silt sized } \\
<25 \% \text { sand sized }\end{array}$ & $<10 \%$ & $\begin{array}{l}\text { Uniform muds with from } 5 \text { to } 10 \% \text { to } 50 \% \text { silt laminae } \\
\text { and thin beds: range of microstructures include } \\
\text { grading, parallel lamination and cross-lamination, } \\
\text { loading structures, scour features, etc; commonly } \\
\text { occur in graded and laminated units }\end{array}$ \\
\hline Silts and sands & $\begin{array}{l}<35 \% \text { clay sized } \\
5-60 \% \text { silt sized } \\
50-100 \% \text { sand sized }\end{array}$ & $<10 \%$ & $\begin{array}{l}\text { Occur in } 10 \mathrm{~cm} \text { to } 10 \mathrm{~m} \text { intervals, thin beds are silty, } \\
\text { normally graded, parallel and cross-laminated; thick } \\
\text { beds are sandy and structureless apart from normal } \\
\text { grading }\end{array}$ \\
\hline $\begin{array}{l}\text { Muddy gravels and } \\
\text { pebbly muds }\end{array}$ & $\begin{array}{l}\text { Sand-silt-clay } \\
\text { admixture, pebbles - } \\
\text { few cm diameter }\end{array}$ & $<10 \%$ & $\begin{array}{l}\text { Structureless units with pebbles dispersed in sand-silt- } \\
\text { mud matrix }\end{array}$ \\
\hline Gravels & $\begin{array}{l}\text { Coarse sand and gravel, } \\
\text { pebbles }<3 \mathrm{~cm}\end{array}$ & - & $\begin{array}{l}\text { Poorly-sorted, clast-supported gravel unit ( }>60 \mathrm{~cm} \\
\text { cored thickness) grading upward into sand }\end{array}$ \\
\hline
\end{tabular}

${ }^{\text {a }}$ Summary characteristics based on Stow et al. (this volume).

pared for thin sectioning (Cremer et al., 1985). As much as possible, samples were selected on the basis of their being representative of particular facies and devoid of visible coring disturbance. Moreover, only sediments that were sufficiently firm to be removed from the core liner without disturbing their internal structures were sampled. Well-sorted granular sediments, such as the thick-bedded silts and sands, could not be treated in this manner.

In the following sections, we outline briefly our methods of sample preparation, describe the range of structures observed, and indicate in which facies they commonly occur. We then describe in detail five examples of the vertical successions of these structures over intervals of 6 to $15 \mathrm{~cm}$. These successions are representative of those found in the four lithologic facies for which we describe them. In our discussion we infer probable mechanisms of deposition.

\section{METHODS}

About 80 vertically oriented quarter-round samples were collected from the cores on board ship. Each round was $3 \mathrm{~cm}$ wide and 6 to $20 \mathrm{~cm}$ long. They were taken from unconsolidated muds, muddy silts, and silts sufficiently firm to be easily removed from the core liner. About 50 of these samples were sliced to about $1 \mathrm{~cm}$ thick, freezedried, and impregnated with an epoxy resin; the impregnated slices were thin sectioned as for hard rocks. The first attempts to impregnate the dried samples failed. However, humidification prior to freeze-drying made impregnation more successful, even for very fine-grained sediment.

The sediment not used for impregnation was subsampled for grainsize analysis. Very small samples $(<1 \mathrm{~g})$ could be analyzed using a "Sedigraph" automated particle-size analyzer.

\section{SEDIMENTARY STRUCTURES}

The range of primary and secondary sedimentary structures observed in our thin sections is described below and illustrated in Figures 2 to 6 . Many of these structures were also recognized during macroscopic description of the Mississippi Fan cores (see site chapters, this volume) and later described from X-radiographs (Coleman, Bouma, et al., this volume). Their occurrence in the different facies is indicated in Table 2. All of these structures have previously been described from other DSDP holes (e.g., Piper, 1973; Bouma, 1975; Nilsen, 1975; Kelts and Arthur, 1981; Stow, 1984).

\section{Homogeneous Bedding}

Homogeneous or massive bedding as observed in thin section refers to sediment without any sedimentary structures at all, which is relatively uncommon, and to sediment in which structures are indistinct to imperceptible. Such bedding characterizes well-sorted coarser-grained sediments (silt and sand facies), fine-grained uniform sediments (clay and mud facies), and sediment that is poorly sorted with a fine-grained matrix (silty mud facies) (Fig. 2A, 2B).

\section{Composite Bedding}

Composite bedding is used to describe the interlayering of beds $(>1 \mathrm{~cm}$ thick) and/or laminae $(<1 \mathrm{~cm}$ thick) with different lithologic or structural characteristics (Figs. 2C, 2D, 3A). This is very common in most of 
Table 2. Main sedimentary structures observed during visual core descriptions and thin section studies and their relative abundances in the four main terrigenous facies.

\begin{tabular}{|c|c|c|c|c|c|c|c|c|}
\hline \multirow[b]{2}{*}{ Structures } & \multicolumn{2}{|c|}{ Sands and silts } & \multicolumn{2}{|c|}{ Muddy silts } & \multicolumn{2}{|c|}{$\begin{array}{l}\text { Silt-laminated } \\
\text { muds }\end{array}$} & \multicolumn{2}{|c|}{ Muds and clays } \\
\hline & Visual & $\begin{array}{l}\text { Thin } \\
\text { section }\end{array}$ & Visual & $\begin{array}{l}\text { Thin } \\
\text { section }\end{array}$ & Visual & $\begin{array}{l}\text { Thin } \\
\text { section }\end{array}$ & Visual & $\begin{array}{l}\text { Thin } \\
\text { section }\end{array}$ \\
\hline Homogeneous bedding & C & C & $\mathbf{P}$ & - & - & - & $\mathrm{C}$ & $\mathbf{R}$ \\
\hline Composite bedding & $\mathbf{R}$ & $\mathbf{R}$ & $\mathbf{P}$ & $\mathbf{P}$ & C & C & $\mathbf{P}$ & $\mathrm{P}$ \\
\hline Normal grading & C & (P) & $\mathrm{C}$ & (P) & $\mathrm{C}$ & $\mathrm{C}$ & $\mathbf{R}$ & $\mathrm{C}$ \\
\hline Inverse grading & - & - & - & - & $\mathbf{R}$ & $\mathbf{P}$ & $\mathbf{P}$ & $\mathbf{P}$ \\
\hline Parallel lamination & $\mathbf{P}$ & C & $\mathbf{P}$ & $\mathbf{P}$ & $\mathrm{C}$ & C & $\mathrm{P}$ & C \\
\hline $\begin{array}{l}\text { Cross-lamination } \\
\text { (foreset) }\end{array}$ & $\mathbf{R}$ & - & - & - & $\mathbf{P}$ & $\mathbf{R}$ & - & - \\
\hline Microcross-lamination & $\mathbf{R}$ & - & $\mathbf{R}$ & $\mathbf{R}$ & $\mathrm{C}$ & $\mathrm{C}$ & $\mathbf{R}$ & $\mathbf{R}$ \\
\hline Mud clasts & $\mathrm{P}$ & $P$ & $\mathrm{P}$ & $\mathrm{P}$ & $\mathbf{R}$ & (R) & $(-)$ & $(-)$ \\
\hline Silt patches and lenses & - & - & (P) & $\mathbf{R}$ & C & $\mathrm{C}$ & - & - \\
\hline Loading structures & - & - & (P) & $\mathbf{R}$ & C & C & - & - \\
\hline Microfaults & - & - & - & - & $\mathbf{P}$ & $\mathrm{P}$ & $\mathrm{P}$ & $\mathbf{P}$ \\
\hline
\end{tabular}

Note. $\mathrm{C}=$ common, $\mathrm{P}=$ present, $\mathrm{R}=$ rare, $-=$ not observed, $(\quad)=$ not readily visible.

the recovered cores and occurs in particular in the siltlaminated mud facies and in parts of the mud and clay facies.

\section{Graded Bedding}

Graded bedding is observed both within single distinct beds and throughout a sequence of interbedded coarse and fine-grained sediments (Fig. 3B, 3C). Grading may be marked by a grain-size variation of the sediment as a whole or indicated by a decrease in size of the coarsest grains only. Normally graded sequences are commonly observed in all the facies studied, as noted also in the macroscopic descriptions. In thin section, many individual laminae often exhibit an inverse grading (Fig. 3E).

\section{Parallel Lamination}

The sediments studied commonly show parallel lamination (Fig. 3B, 3E). This may be defined by distinct planar and continuous laminae or by discontinuous thin laminae which mainly occur in the silt-laminated mud facies. In coarse silt, a crude parallel lamination is shown by the alignment of the coarsest particles or by aligned mud lenses (Fig. 3D). The muds and clays with a homogeneous appearance commonly show extinction of the entire thin section in cross-polarized light, indicating an orientation of grains along the stratification plane (Fig. 4A, 4B).

\section{Cross-Lamination}

During shipboard core description, cross-lamination was commonly noted in silt beds within the silt-laminated mud facies. Only one thin section (Fig. 2C) from this facies shows foreset bedding over the entire sample width, with a change in sediment composition across the sample. In other sections smaller scale isolated ripple shapes and wavy ripple bedding are observed (Fig. 5B, $5 \mathrm{C})$. It should be noted, however, that because of the narrow width of the samples, very low-angle cross-lamination cannot be identified.

\section{Discontinuous and Irregular Structures}

Discontinuous and/or irregular patches of material within a sample of varying composition are common in all facies (Figs. 5A, 6A, 6C). These are referred to as lenses, blebs, or mottles, in order of increasing irregularity. In many cases, we interpret them to be of primary current origin (i.e., microripples, rip-up clasts) or the result of either synsedimentary deformation (loading structures, flames, pseudo-nodules) or rapid deposition of a poorly sorted sediment. In other cases, they may be the result of animal activity (burrows, pellets).

\section{Microfaults and Loading Structures}

With the silt-laminated mud facies, microfaults are clearly indicated by an offset of laminae. In more muddy sections, we observe only a grain reorientation along oblique planes that is best visible in cross-polarized light (Fig. 4A, 4B). Microfaulting either affects the entire sample or is seen to disappear downward and upward into regular bedding. The latter case suggests synsedimentary faulting.

More plastic deformations are also combined with faulting in some sections. This association gives rise to a confused pattern (Fig. 6B) in which the real primary structures (cross-ripple, or lenticular bedding) cannot be clearly distinguished from secondary structures (sediment stretching, slumping, or injection).

Certain structures (irregular bedding, microfolds, partial sediment mixing), which were observed within a sample of interlayered mud and silt (Fig. 6D, 6E), have more likely resulted from load casting within a very soft and rapidly deposited sediment than from slumping.

\section{VERTICAL SUCCESSIONS OF STRUCTURES}

The sedimentary structures described above commonly occur in particular associations or vertical successions over an interval of $5 \mathrm{~cm}$ to more than $1 \mathrm{~m}$. Where these structures are organized systematically [e.g., graded laminated units of Piper (1972)], often in association with vertical grading, we refer to the complete unit or bed as a sequence. In the following section, we describe the vertical successions of structures from detailed study of five thin sections. These examples are representative of the four major fine-grained lithological facies from the Mississippi Fan sediments. 


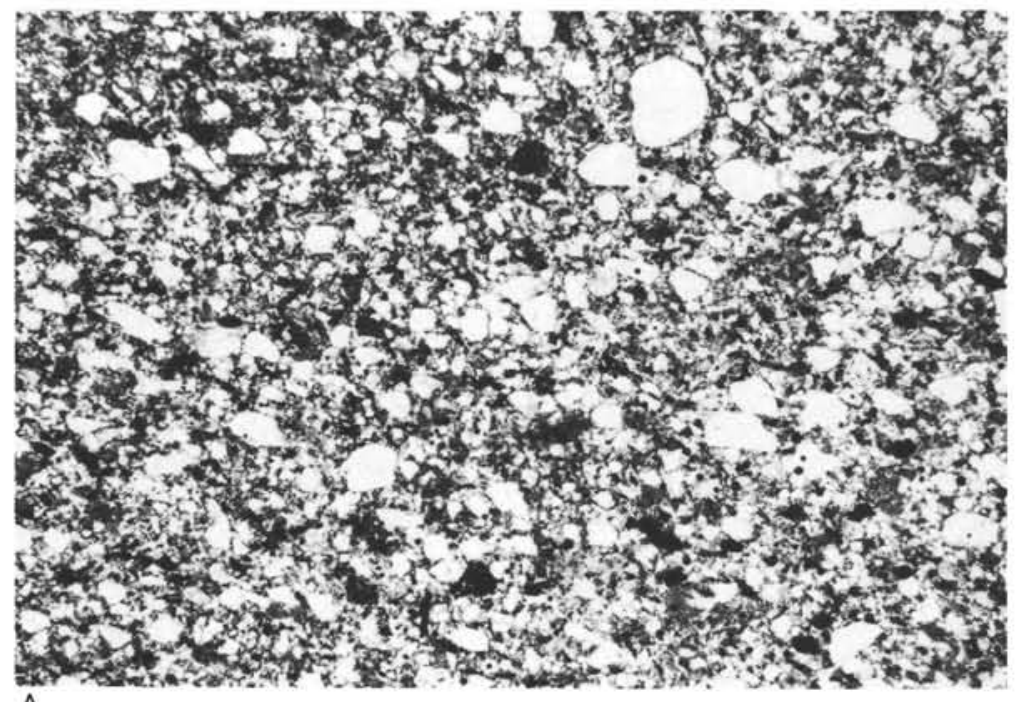

A

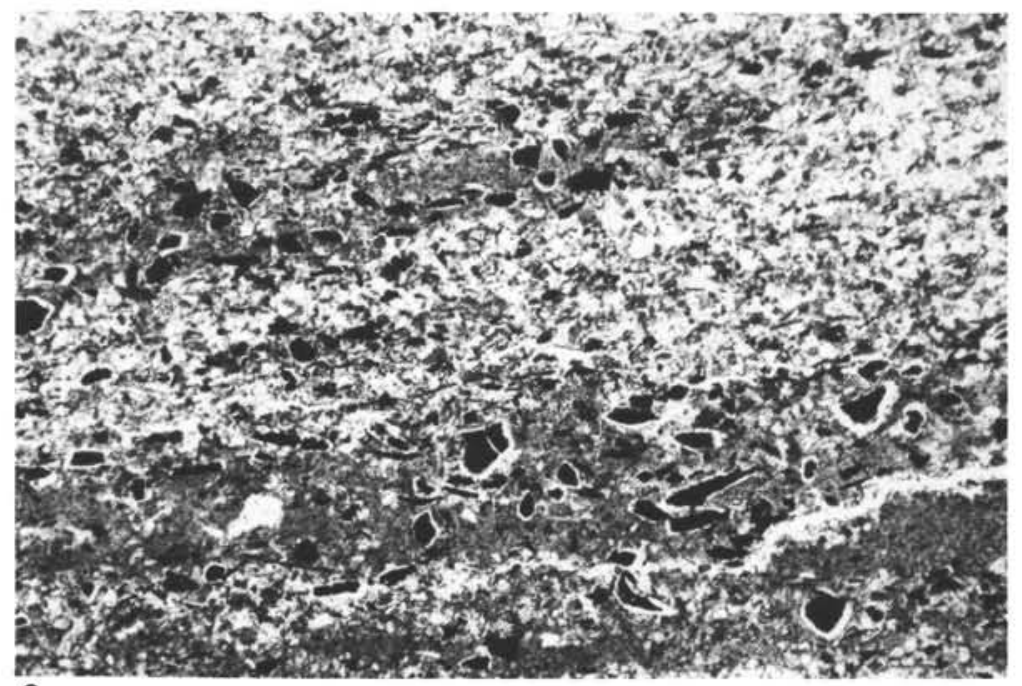

C

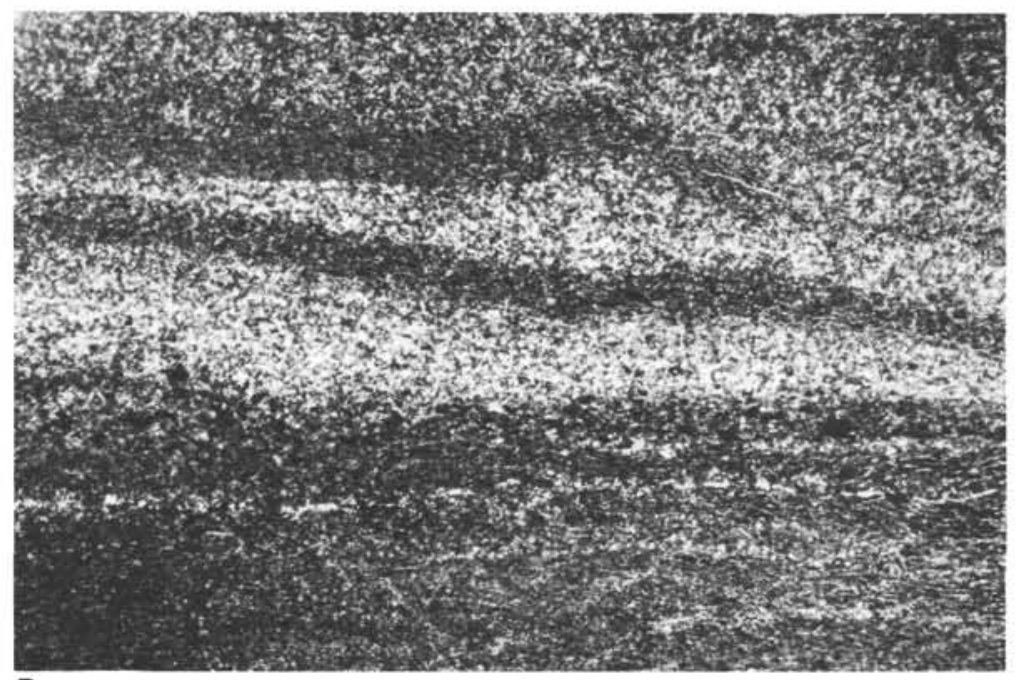

D

Figure 2. Microphotographs from (A) Sample 615-23-1, 59-65 cm, homogeneous coarse-grained silt; (B) Sample 614-3-1, 120-126 cm, coarse quartz grains dispersed in a muddy matrix; (C) Sample 614-3-1, 120-125 cm, foreset bedding of mud, bearing lignite grains and silt laminae; (D) Sample 616B-17,CC (24-30 cm), composite bedding, with thin planar silt laminae (lower part) and wavy lamination (upper part); (E) Sample $617-2-5,129-135 \mathrm{~cm}$, fine-grained mud, bearing rare foraminifers, maximum lighting in cross-polarized light.

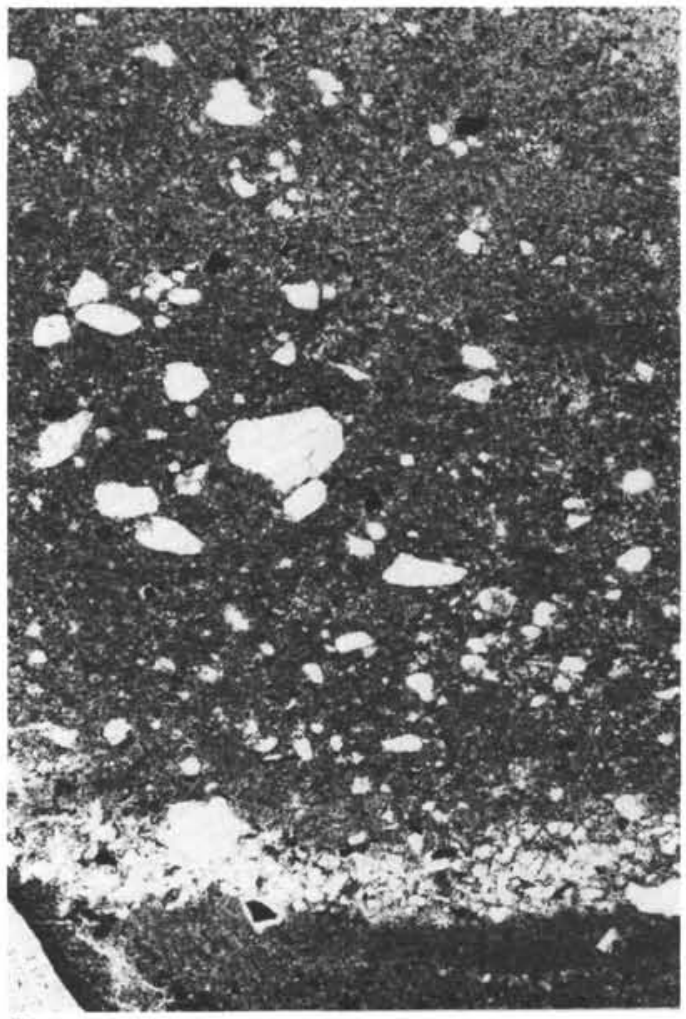

B

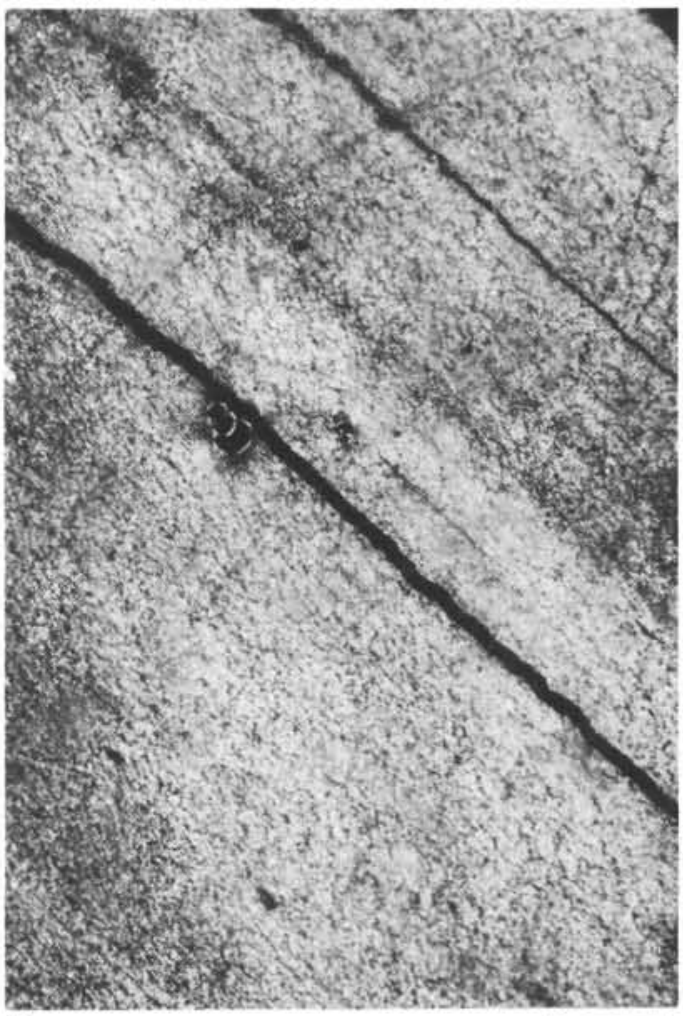

E 


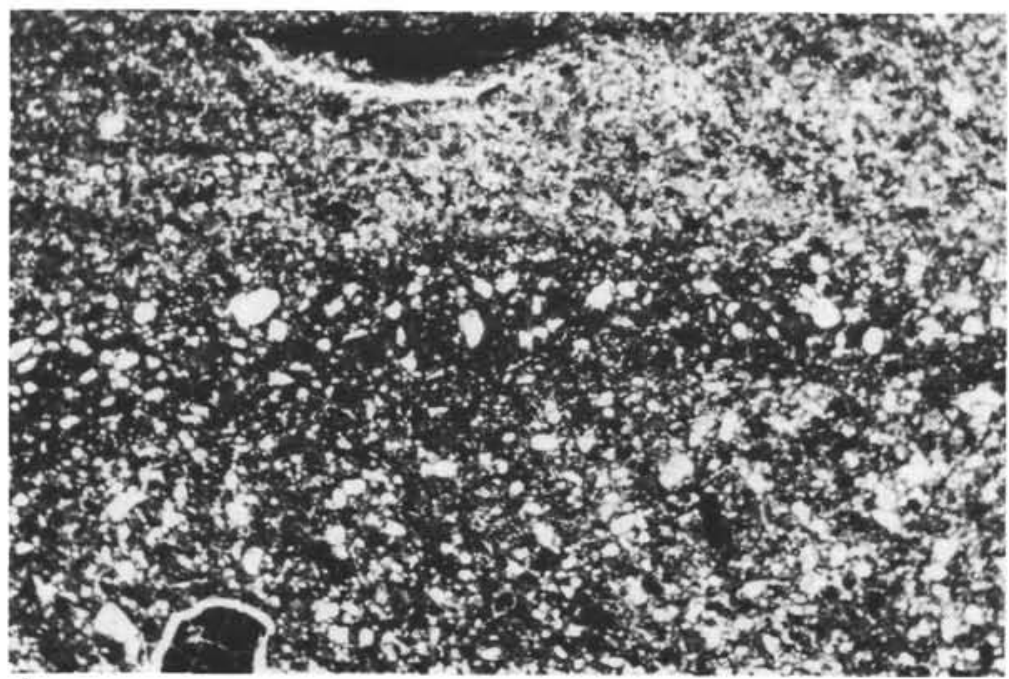
A
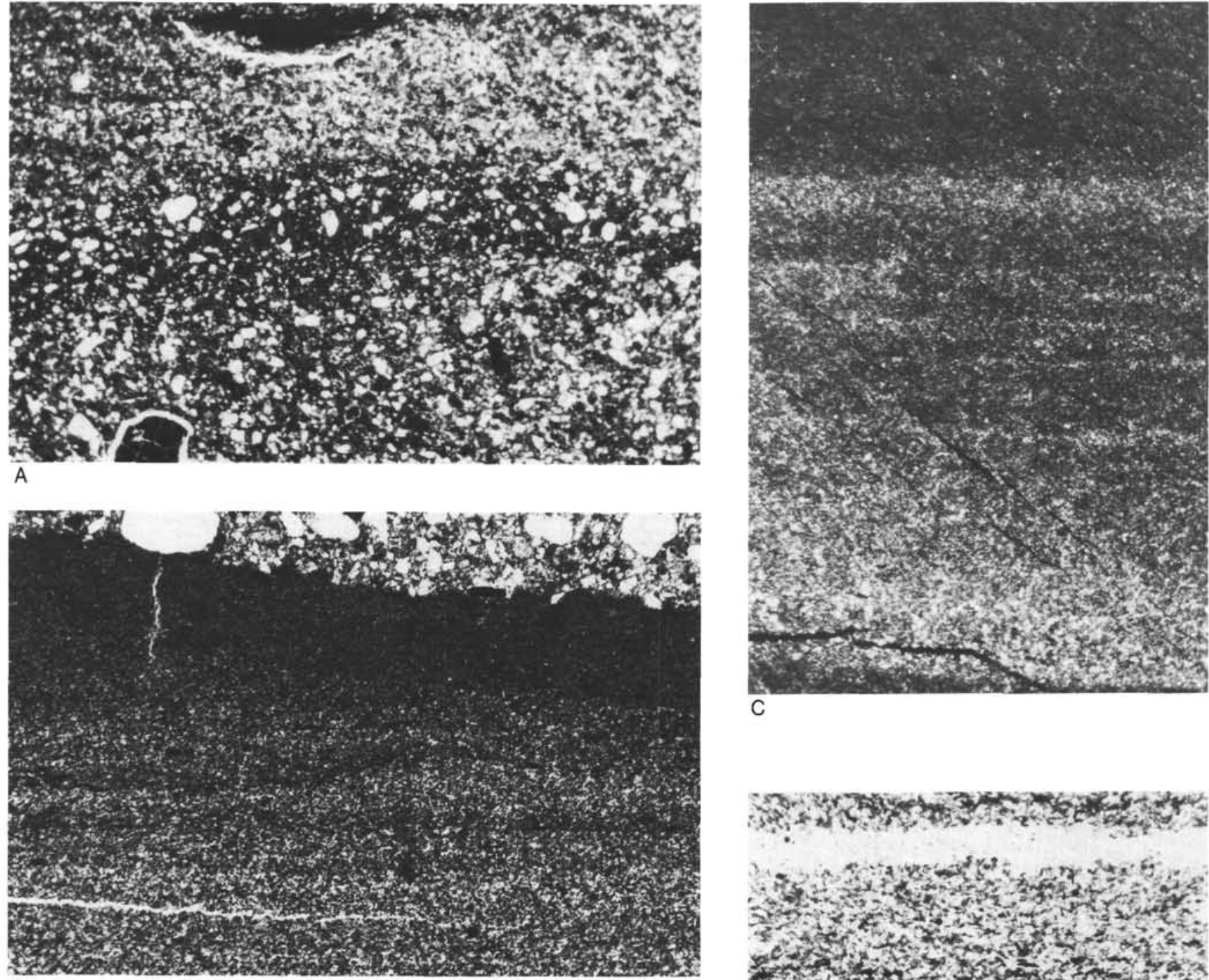

C

30.
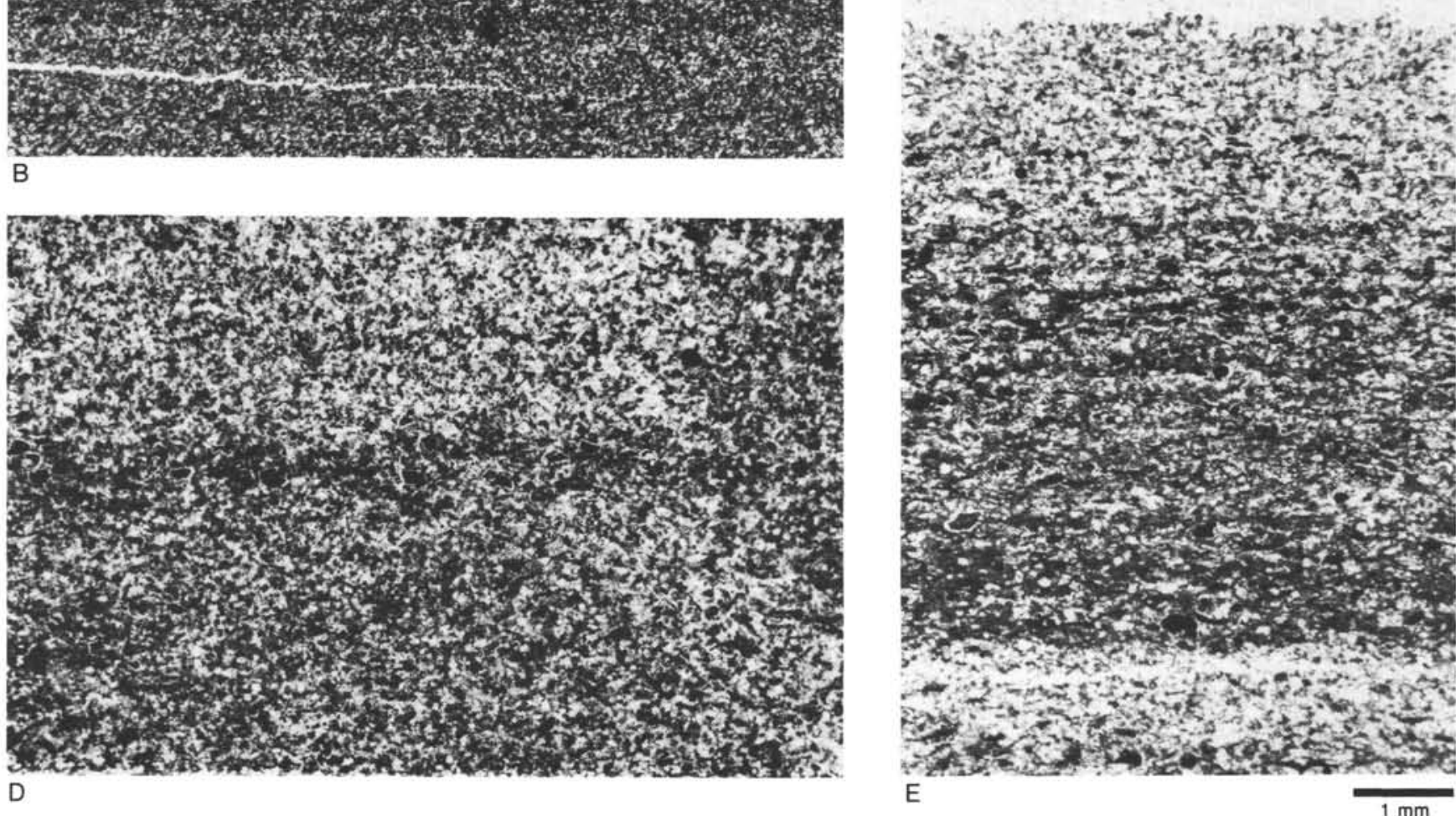

D

$1 \mathrm{~mm}$

Figure 3. Microphotographs from (A) Sample 615-47-1, 34-40 cm, single dark muddy lamina between homogeneous beds of muddy silt; (B) Sample $615-33-2,35-42 \mathrm{~cm}$, normally graded sequence from silt through mud-laminated silt, to graded then homogeneous mud; (C) Sample $616 \mathrm{~B}-15, \mathrm{CC}(7-13 \mathrm{~cm})$, normally graded silt laminated mud unit; (D) Sample 622-21-1, 62-66 cm, lignite grains emphasizing parallel lamination in a silt; (E) Sample 615-11-4, 98-104 cm, inverse grading from muddy silt upward into a clean silt. 

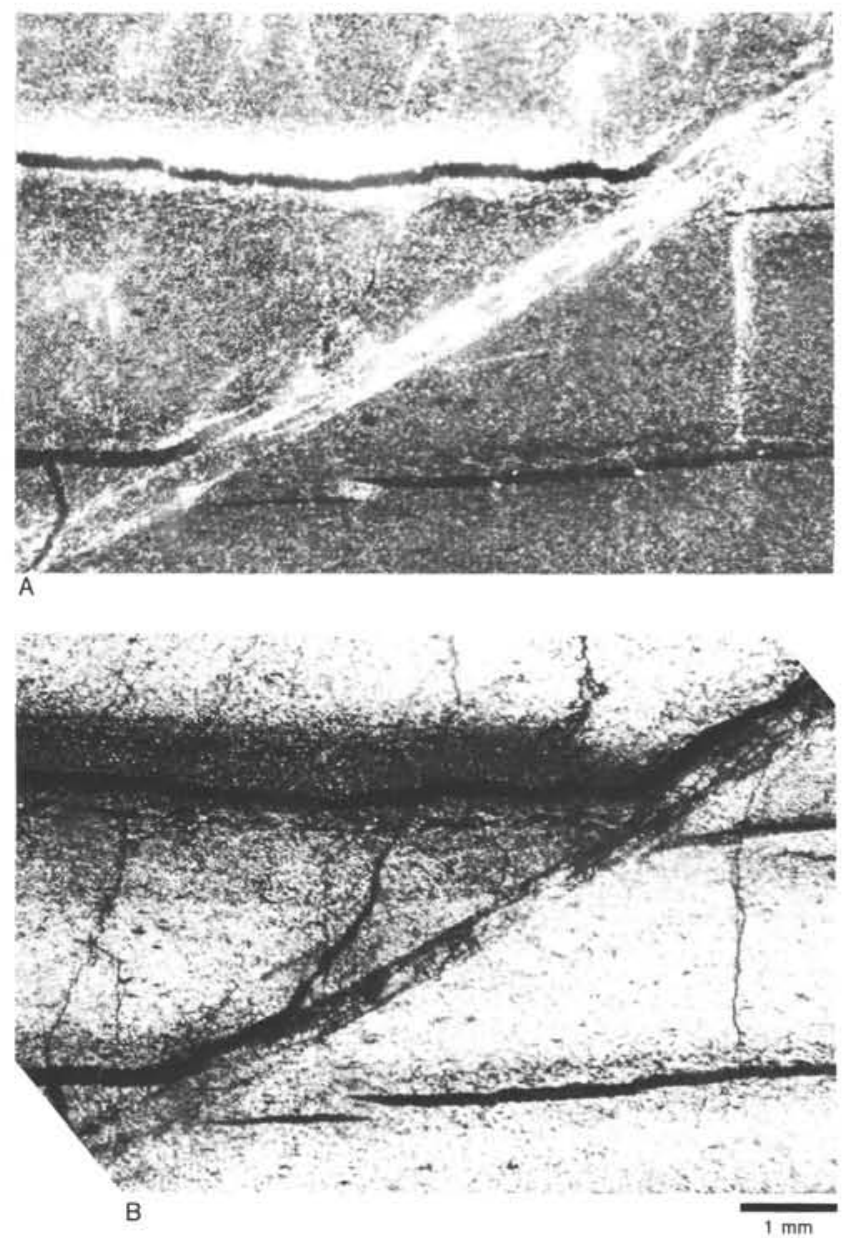

Figure 4. Microphotographs from Sample 616-5-6, 75-81 cm. Both taken in cross-polarized light; (A) at extinction and (B) at $45^{\circ}$ to extinction (maximum lighting). The extinction characteristics of the mud and silt laminae show that grain alignment is parallel to bedding and that grains have been reorientated parallel to the microfault plane.

\section{Silt and Sand Facies}

The few samples collected from clean coarse-silt layers exhibit only very poor structures (mostly crude planar lamination). This absence of structure may, however, be the result of flow-in during coring because of the high water content of the silts. Finer grained or more poorly sorted silts exhibit better structures than the coarse-silt layers.

Sample 622-21-1, 62-74 cm (Fig. 7) was selected from the middle of a 60 -cm-thick sequence that fines upward from sand to silt and includes numerous black laminae throughout and irregular dark brown mud laminae in its upper part. The bottom of the thin section shows coarse, well-sorted silt. Elongated grains emphasize a crude planar stratification. Grain size and mineralogical variations define several laminae rich in lignite particles. The silt is overlain by a mud layer that contains discontinuous thin silt laminae. The mud layer appears to have been secondarily disrupted. Toward the top of the thin section there is an increase in the number of mud intervals that occur as isolated blebs, discontinuous layers, or lenses interbedded with silt. The silt in the upper part of the section is very similar to that observed in the lower part, except for a slight decrease in grain size (median decreased from 35 to $30 \mu \mathrm{m})$.

The slight fining of silt and the increase in mud proportion upward support our shipboard interpretation that we are dealing with a single turbidite sequence. The structural characteristics of mud layers may reflect primary or secondary mechanisms. However, because the silty muds show a bedding more or less parallel to the silt beds, it is difficult to argue that they are rip-up clasts that were deposited simultaneously with the silt. They may be better interpreted as the result of very rapid deposition from a relatively fast moving and unstable current.

\section{Muddy Silt Facies}

The muddy silt facies, bearing lignite grains, was commonly found within normally graded sequences that range upward from cleaner silt to silty mud. This facies either appears massive or shows a regular bedding emphasized by darker laminae. Sample $615-33-2,29-42 \mathrm{~cm}$ was taken from such a facies. The thin section comprises the uppermost part of such a sequence and the bottom part of another 40-cm-thick sequence that contains several layers, each about $1.5 \mathrm{~cm}$ thick and separated by darker laminae (Fig. 8).

The top of the lower sequence grades from a fine silt with mud laminae to a silty mud (a on Fig. 8). Although the base of the upper sequence is sharp, it molds rather than erodes the wavy top of the lower sequence. The upper sequence consists of a matrix of muddy silt $(\sim 30 \%$ grains $<2 \mu \mathrm{m}$ ) with coarser (up to $400 \mu \mathrm{m}$ ) grains of quartz and lignite. Near its base, a discontinuous mud lamina, containing coarse quartz, shows oblique stratification (b). It is overlain by a layer $1 \mathrm{~cm}$ thick (c) that has a concentration of coarse grains in its center. Darker colored, very thin laminae (L) start to appear and become more distinct and more regularly spaced in the upper part of the thin section. These laminae are of equal thickness and separate beds of identical character.

Although the darker laminae appear to contain a greater clay fraction on visual inspection, grain size analyses failed to confirm this observation. The property that highlights the laminae appears to be related to a rapid change in grain fabric. This is supported by the observation that there is a larger proportion of coarser grains in the middle of the laminae and also better grain alignment.

In this example, the presence of coarse grains in a finer matrix and the general homogeneity of the sediment between each bed suggest rapid deposition from a single turbidity current. Changes in bedform, similar to the ripple shape present in the bottom part of the sequence, may explain the formation of the darker laminae. However, this structure may more likely result from cyclic changes in turbidity current flow, marked by phases of rapid deposition (structureless silty mud) and possibly phases of less rapid deposition allowing a more ordered fabric to develop (thin dark laminae) (cf. Lowe, 1982). 

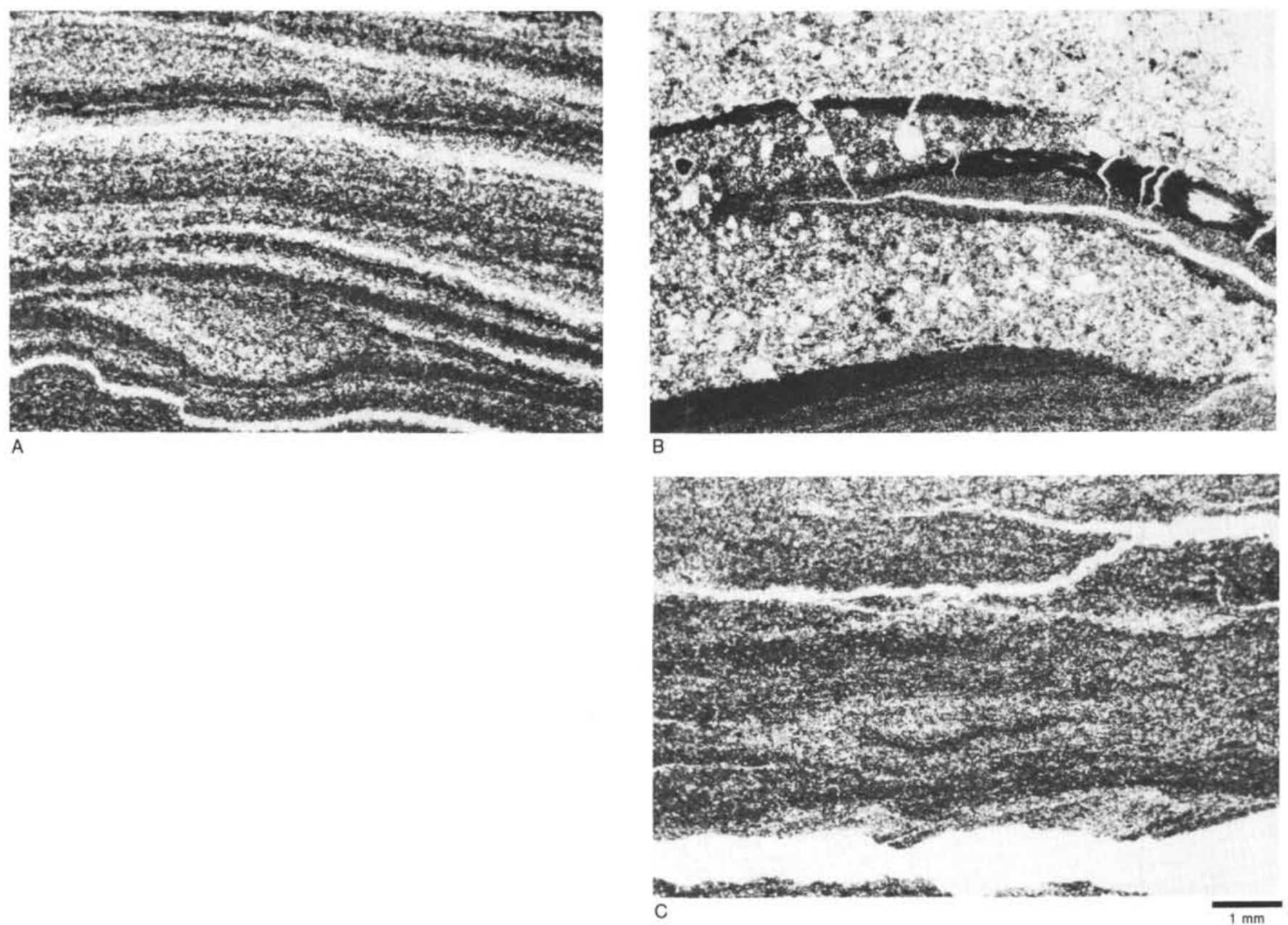

Figure 5. Microphotographs from (A) Sample 617-3-5, 133-139 cm, continuous thin silt and mud laminae and lens, which seems to originate from a ripple; (B) Sample 615-33-2, 35-41 cm, cross-lamination at base of coarse muddy silt layer. Ripple shapes are capped by discontinuous finegrained silt and mud laminae; (C) Sample 615-11-4, 12-22 cm, fading ripples (lenticular silts with muddy troughs) grading upward into indistinct, wavy, silt-mud lamination.

\section{Silt-Laminated Mud Facies}

This facies is the dominant lithologic facies cored on the Mississippi Fan during Leg 96. It varies widely between sections containing less than $10 \%$ silt laminae and sections comprising up to $50 \%$ silt laminae. The silt layers occur in units ranging from thin laminae to about 10-cm-thick beds within muds which are either laminated, color banded, or structureless. A great variety of sedimentary structures, which are interpreted to be of turbidity current origin, can be recognized in this facies. Two examples illustrate the chief characteristics of this facies in thin section.

Sample $614-3-1,120-126 \mathrm{~cm}$ contains a 3 -cm-thick silt bed within a laminated silty mud. The base of the thin section (Fig. 9) is a fine-grained mud (a) that shows planar lamination in polarized light. Overlying this is a mud layer (b) with discontinuous silt laminae at its base and some scattered coarse grains. The mud grades upward, through interbedded silt and mud (c) into laminated silt (d). The interbedded silt and mud exhibit an oblique wavy stratification; the mud laminae that contain lignite grains pass laterally into silt laminae. The overlying silts (d) are finely laminated and well sorted; they contain two layers $(1,2)$ in which the proportion of mud and lignite grains is greater, the lower of which (1) exhibits oblique stratification. In the upper part of the section the general fining-upward trend continues: silty mud with silt laminae (e) changes into a graded mud (f) and then into a foraminifer-bearing mud (g). Although this mud is very fine grained ( $90 \%$ clay), it still appears laminated in cross-polarized light. The microfault observed in the silt bed (d) does not reach the upper muddy beds, which indicates that it is synsedimentary.

The graded silt-mud sequence and the observed sedimentary structures suggest deposition from a turbidity current (c to e). Nevertheless, its limits are not clearly defined. The muddy interval underneath the silt (b) could be interpreted as the result of a distinct event, but it more likely constitutes the base of the turbidite sequence because it does not really differ from the muddy laminae above. This mud either represents rapid deposition of suspended sediments (crude lamination, poor sorting) prior to a traction phase (well-defined laminae, good sorting) or deposition from the head of a turbidity current, followed by deposition from the body of such a 


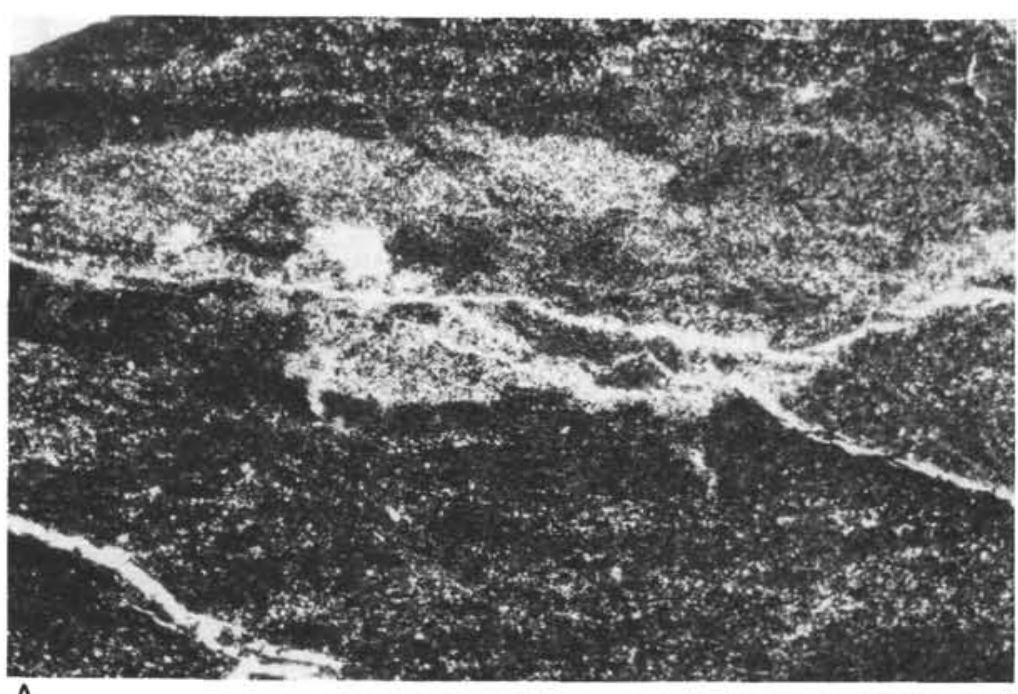

A
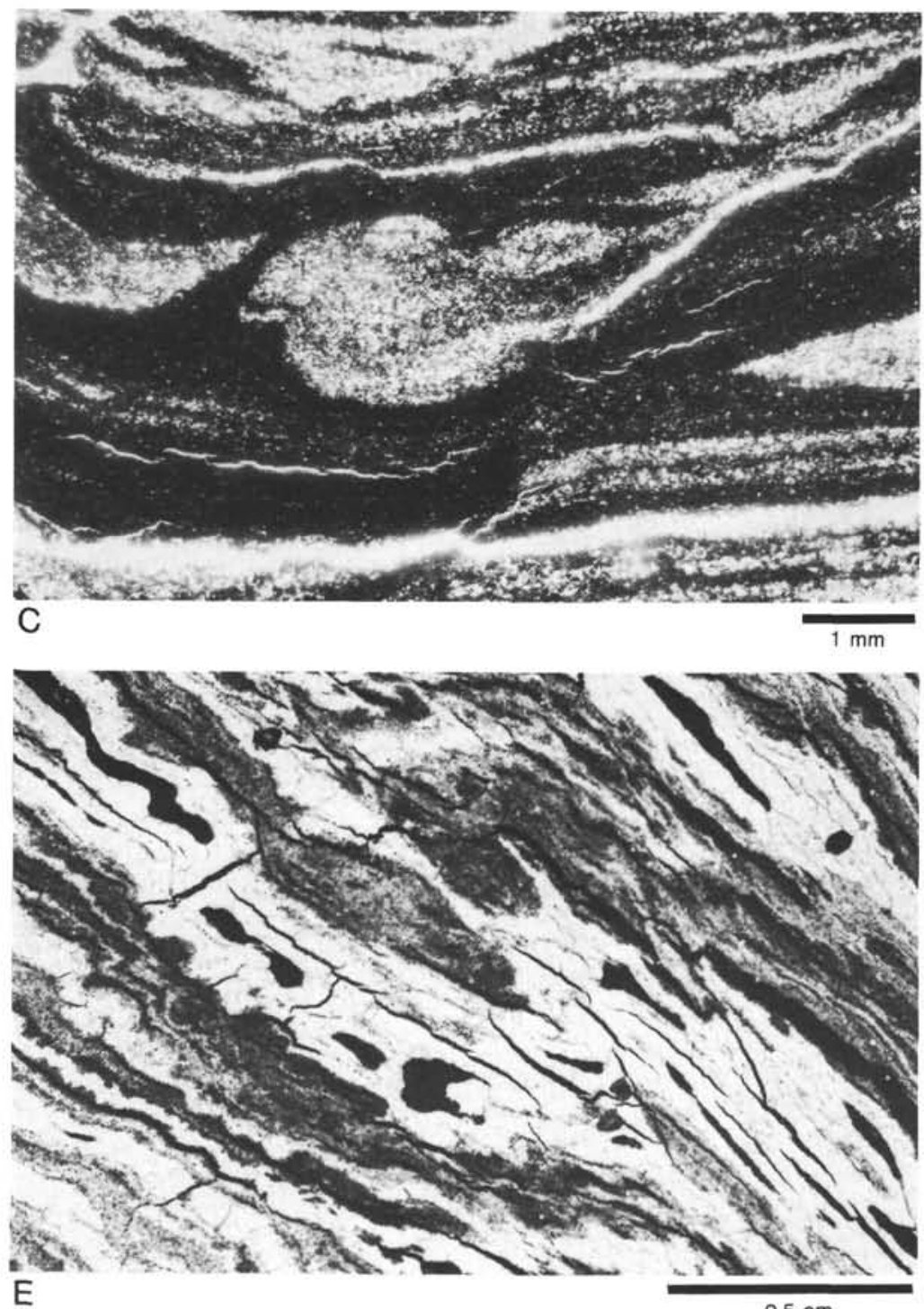

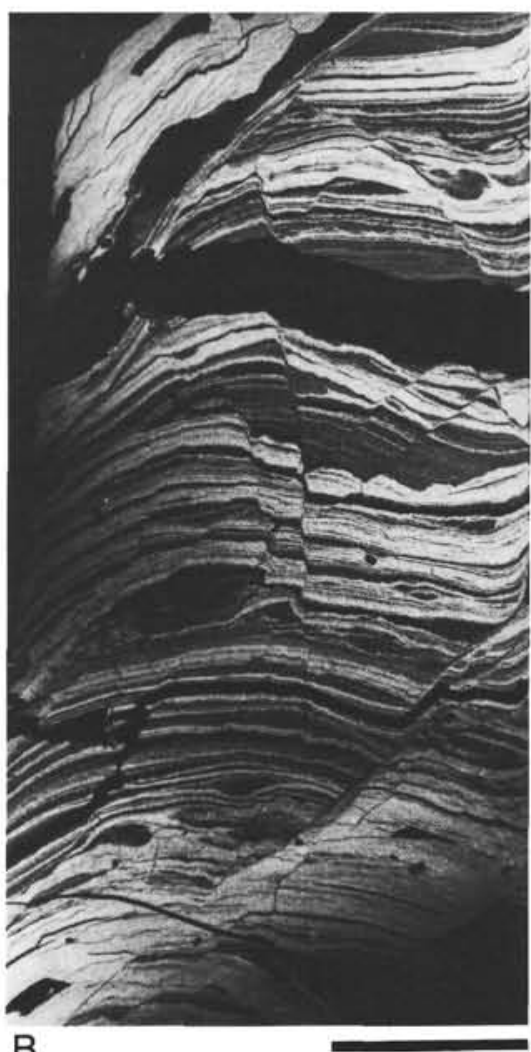

$1 \mathrm{~cm}$

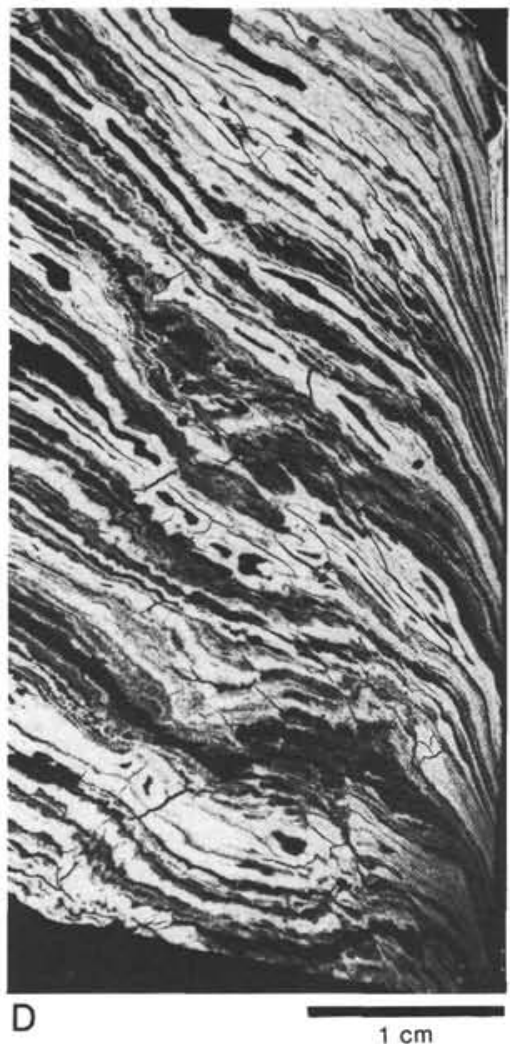

Figure 6. (A) Microphotograph from Sample 616-34-4, 0-6 cm, irregular patch within a silty mud; (B) negative picture of thin section of Sample 617-3-5, 133-139 cm, silt and mud laminae deformed by microfaulting and load casting; (C) detail of B, showing pseudonodule; (D) negative picture of thin section of Sample 617-5-1, 107-113 cm, mud and silt laminae deformed by load casting and partial flow; (E) detail of $\mathrm{D}$, showing microfolds and silt injections within mud. 


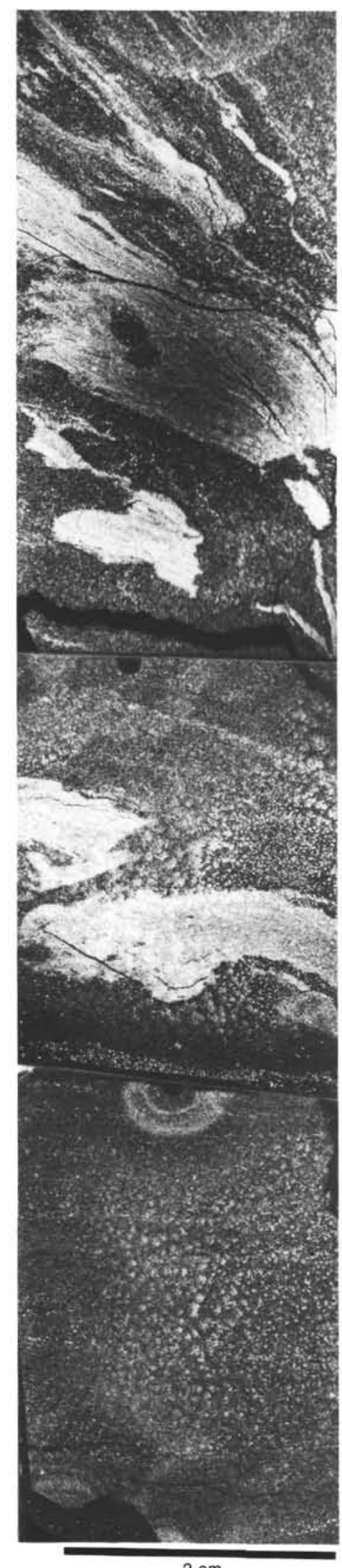

$2 \mathrm{~cm}$

Figure 7. Negative picture of thin section of Sample 622-21-1, 62-74 cm from silt and sand facies. Part of 60 -cm-thick graded bed; photograph shows slight normal grading and an upward increase in irregular mud layers and patches. Detail of lower silt in Figure 3D.

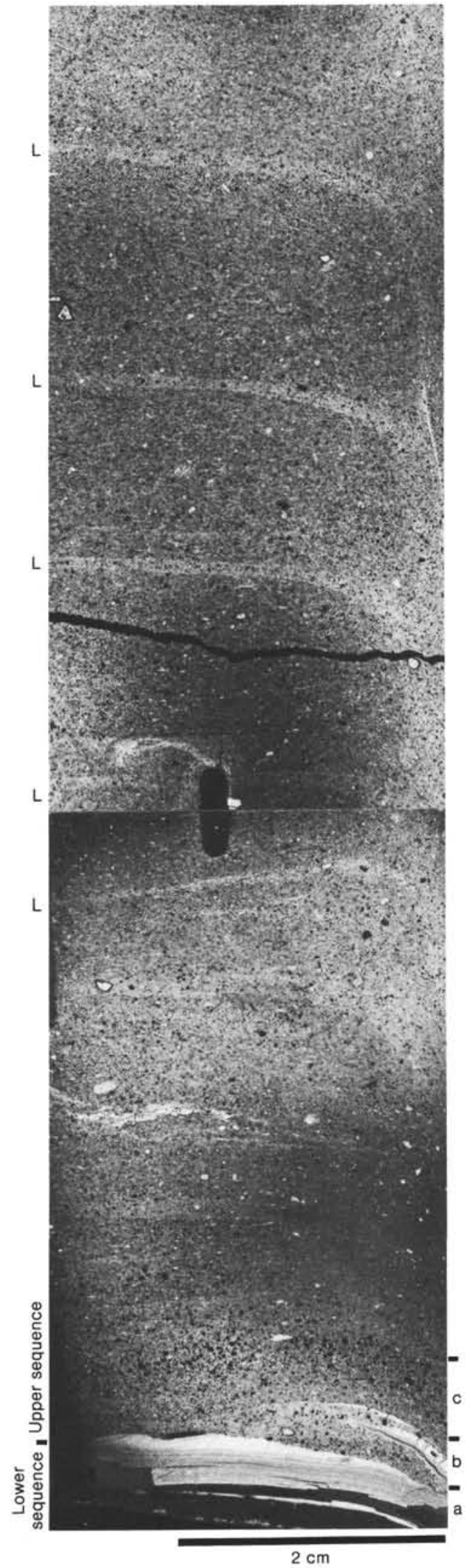

Figure 8. Negative picture of thin section of Sample 615-33-2, 29-42 cm from muddy-silt facies. Lower part of 40 -cm-thick graded bed, with sharp base over underlying unit. Note slight normal grading and presence of thin, dark (light in this negative picture) and muddy laminae (L) between homogeneous silty mud layers. Details of layers (a) and (b) in Figures 3B and 5B. 


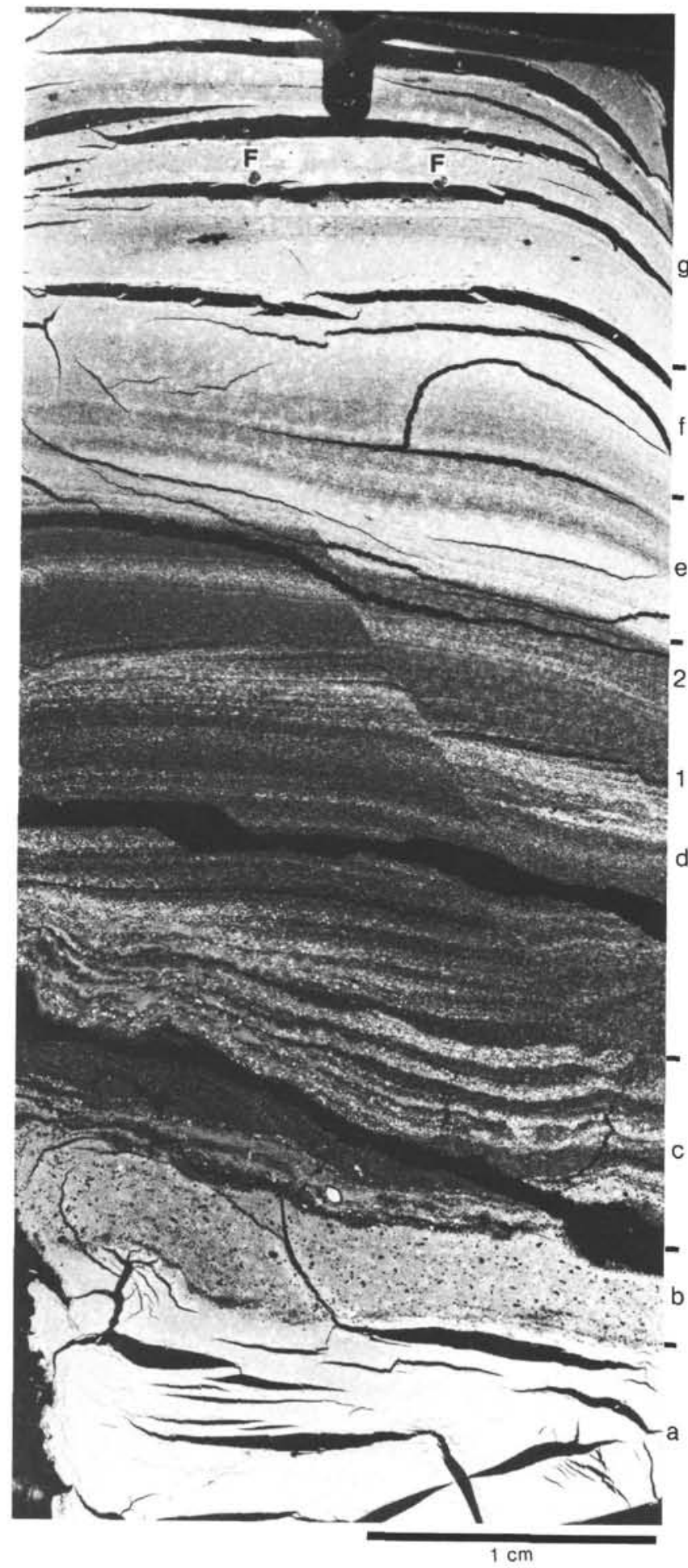

Figure 9. Negative picture of thin section from Sample 614-3-1, 120$126 \mathrm{~cm}$, from silt-laminated mud facies. Photograph shows graded-laminated unit (b-g) over fine-grained mud (a). $\mathrm{F}=$ isolated foraminifers. Detail of layer (b) in Figure 2B, and detail of layer (c) in Figure 2C.

current (Chough and Hesse, 1980). At the top of the turbidite sequence, the presence of pelagic foraminifers in a very fine mud $(\mathrm{g})$ may represent a hemipelagic interval that overlies the turbidite. However, this mud still contains planar lamination and no bioturbation. Thus either the deceleration of the turbidity current was sufficient to allow some pelagic forms to settle out with the fine mud from its tail, or this mud represents deposition from some type of bottom-current-driven nepheloid layer that occurred rapidly enough to limit bioturbation.

The second example (Sample 615-11-4, 98-104 cm) was collected from a unit, $10 \mathrm{~cm}$ thick, comprising about 20 laminae. During shipboard description, this was interpreted as a graded laminated unit deposited from a single turbidity current. In thin section the overall characteristics of the sediment show little or no vertical variation (Fig. 10). However, the sedimentary structures are emphasized by an alternation in grain size between clean silt laminae (median $15 \mu \mathrm{m}, 10 \%<2 \mu \mathrm{m}$ ) and muddier laminae (median $10 \mu \mathrm{m}, 30 \%<2 \mu \mathrm{m}$ ). In the lower part of the thin section we observe fading ripples, overlain by a more distinct wavy cross bedding, and a layer with crude planar stratification. The upper half of the thin section shows only very thin, horizontal, internal lamination within distinct thick laminae. The majority of these thick laminae appear inversely graded, starting with a muddy silt with scattered coarse grains at their base and topped by a clean silt. The grain size distribution within a lamina thick enough to be subsampled (Fig. 8, sample numbers 1,2) confirms this observation. The proportion of finer grains decreases upward and the sorting increases, whereas the proportion of coarser grains shows only a slight upward decrease, so that the mean grain size change indicates inverse grading.

Based on the observed sedimentary structures, we interpret this whole section as a Bouma (1962) $\mathrm{T}_{\mathrm{c}-\mathrm{d}}$ turbidite sequence. However, the inversely graded laminae are not a recognized characteristic of the $T_{d}$ division. Their formation may be linked to some process of depositional sorting through the boundary layer at the base of the turbidity current (Stow and Bowen, 1978; Hesse and Chough, 1980).

\section{Mud and Clay Facies}

Based on our shipboard core descriptions, the mud and clay facies can be subdivided into sparsely laminated muds and homogeneous muds.

The laminated muds of this facies, as opposed to the silt-laminated mud facies, contain very few thin silt laminae and exhibit only color banding. Thin sections from this facies (Figs. 2E, 3) contain well sorted silt laminae, 1 to $3 \mathrm{~mm}$ thick. Generally, these laminae are irregular and exhibit a sharp lower contact and a gradational upper contact with mud. The mud can contain a range of silt structures from distinct very thin laminae to irregular silt lenses or patches. Even the apparently homogeneous mud intervals exhibit a planar stratification in crosspolarized light. Vertically graded sequences from silt to homogeneous mud through thinly silt-laminated mud have been observed, but the thin section study failed to reveal any repetitive sequence of structures (e.g., Stow and Piper, 1984). A few foraminifers are present within this facies, either reworked in a silt lamina, or dispersed within the mud layers. In all the thin sections, we only observed one thin muddy layer with abundant small foraminifers that could be interpreted as a hemipelagic interval. 

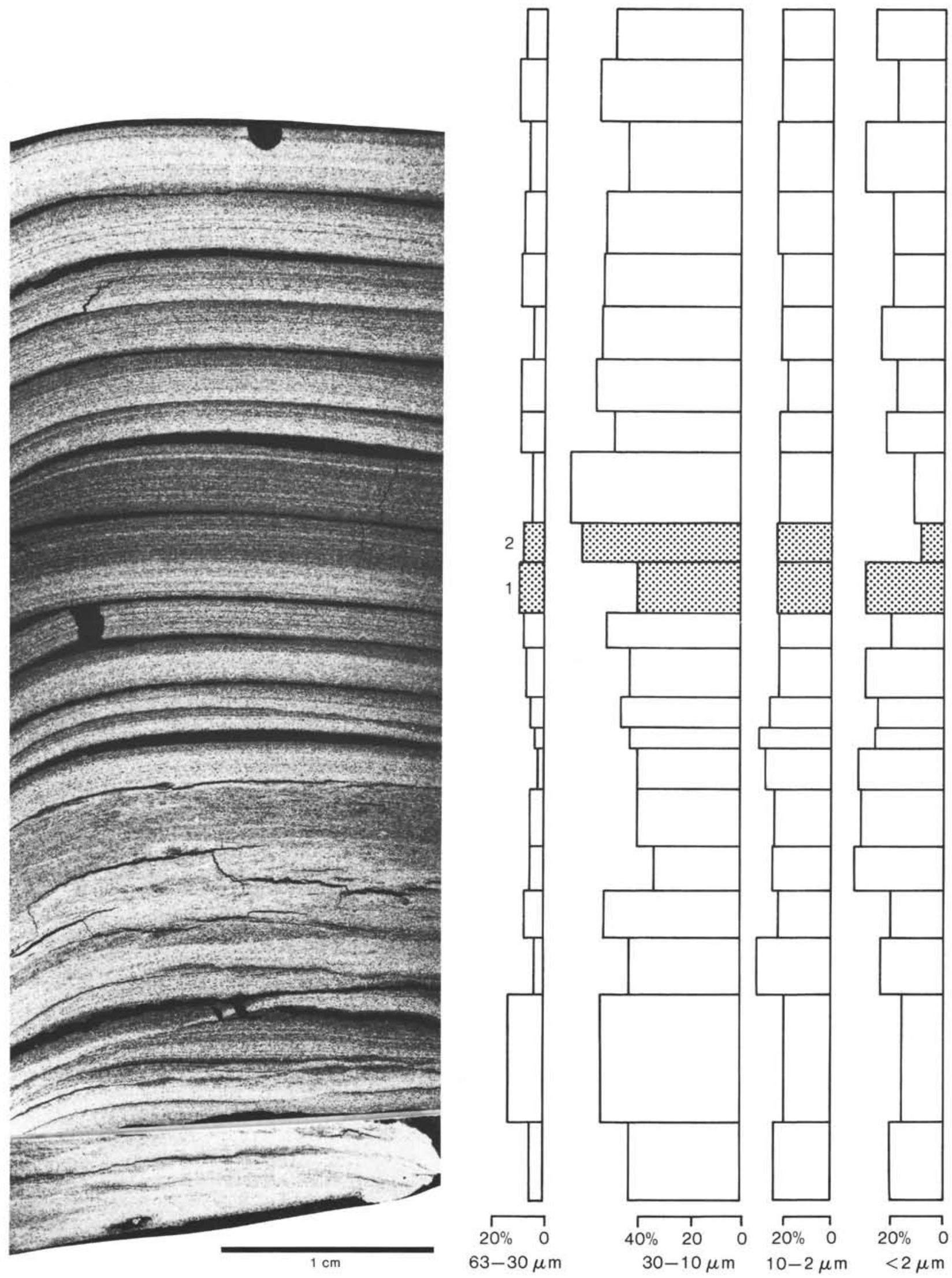

Figure 10. Negative picture of thin section from Sample 615-11-4, 98-104 cm from silt-laminated mud facies. Photograph shows part of 10 -cm-thick graded-laminated unit. Bar scales to right show results of grain size analyses of individual layers. Each thick lamina in upper part of section appears to be inversely graded from muddy silt (lighter) to clean silt (darker) and is internally microlaminated. Grain-size analysis within single thick lamina $(1,2)$ shows the nature of this inverse grading. 
The thin section observations show that there is no major difference in structure or grain fabric between the muddy intervals of the silt-laminated facies and the laminated muds of the clay and mud facies. These muds or clays (the clay proportion can exceed $70 \%$ ) may also be interpreted as fine-grained turbidites. However, it is difficult to define the limits of each turbidite event or to distinguish the deposits of low density turbidity currents from the deposits of bottom-current nepheloid suspensions.

Essentially structureless clays and muds constitute an important part $(25 \%)$ of the recovered sediment at Site 616. These "homogeneous" muds commonly form unbedded intervals up to several meters in thickness with irregular color variations and scattered silt pockets. In a number of core sections, indistinct laminae that are slightly darker and commonly 1 to $2 \mathrm{~cm}$ apart were observed. This structure, similar to that described above for the muddy silt facies, was initially explained by coring disturbance.

Four samples were taken from Section 616-34-1 which exhibits these distinct 1-cm-spaced darker laminae in its lower part and an indistinct layering of fine mud and silty mud with silt blebs in its upper part. Thin sections from the lower part (Samples 616-34-1, 136-142 cm and $108-114 \mathrm{~cm}$ ) are almost structureless (Fig. 11A). The sediment is a silty mud with dispersed coarser grains up to $50 \mu \mathrm{m}$. The darker laminae are poorly distinguished in natural light. They are more clearly visible in cross-polarized light, suggesting that the grains are elongated along the stratification plane, the orientation of grains being more random in the intervening beds. A similar structure is observed in the thin section (Sample 616-34-1, $53-59 \mathrm{~cm}$ ). The sediment is, however, finer grained and slight variations in grain size as well as fabric define a more distinct parallel lamination (Fig. 11B). The thin section (Sample 616-34-1, 9-15 cm) from the top of this core section consists of a graded sequence that contains successively from bottom to top: a mud layer with clean silt pockets, interbedded mud layers and discontinuous silt laminae, mud with thin planar silt laminae (Fig. 11C), and a fine laminated mud.

The observations on these microstructures, their probably very rapid sedimentation rate, the absence of biogenic content, and an average grain-size larger than that of the earlier described laminated mud facies, all suggest that the homogeneous mud facies most likely originated from turbidity currents. Moreover, several arguments based on core description and thin section study suggest that the regularly spaced darker laminae within this facies are primary structures rather than features induced by coring disturbance because: (a) they often extend to the core liner where they are normally bent, (b) they characterize the siltier mud only, as well as parts of the muddy silt facies (above); (c) thin silt laminae occur with the same regular spacing in certain parts of other core sections; and (d) the finer-grained muds exhibit a distinct parallel bedding and color changes matching grain-size variations. Consequently the 1.20 -m-thick unit within Section 616-34-1, which exhibits an upward trend from coarse, poorly sorted sediment and spaced laminae to a finer, better sorted, entirely laminated sedi- ment, is interpreted as a single thick muddy turbidite rather than a succession of thin turbidites.

\section{DISCUSSION}

Thin section study of samples collected from late Wisconsin glacial deposits of the Mississippi Fan revealed various primary sedimentary structures which are interpreted, for the most part, as representative of turbidites. Structures characterizing hemipelagic deposits are rare. This indicates a high frequency of density flows during the construction of the youngest Mississippi Fan lobe.

As observed during shipboard description of cores, there is a continuum of sedimentary structures between the thicker-bedded coarser turbidites and thinner-bedded finer turbidites. However, the small number of samples and their small size prevents a more systematic analysis of the types of structures and their vertical successions.

This study mainly dealt with fine-grained sediments and therefore the more commonly observed structures are best described using the Stow model of turbidite sequence (Stow and Shanmugam, 1980), which is equivalent either to the base-absent $\mathrm{T}_{\mathrm{d}-\mathrm{e}}$ Bouma (1962) sequence or to the Piper (1978) E1-E3 units. Fully developed Stow sequences are uncommon: the lower units are frequently missing (base absent units; Stow, 1984), the mud frequently remains finely laminated up to the top of the graded sequence, and the $T_{a}$ unit (microbioturbated mud) is commonly indiscernible (top-absent units). Moreover, the vertical sequences vary widely from samples with regular distinct sequences to samples showing irregular bedding and very partial turbidite sequences of structures.

Several of the structures observed do not fit clearly into any of these standard structural sequences for finegrained turbidites and are less readily interpreted. They include: (a) very thin, dark, regularly spaced laminae within thick, otherwise structureless, mud and muddy silt beds; (b) the apparent reverse grading of individual laminae within a silt-laminated turbidite unit; (c) the irregular interlayering of silt and mud laminae, lenses, and blebs; and (d) the occurrence of isolated mud lenses in more massive silt layers.

Although we do not attempt to interpret the exact mechanisms for the origin of each of these structures here, we suggest that they are of primary current origin resulting, in some way, from rapid deposition from large-scale muddy turbidity currents. The various types of lamination probably reflect sorting processes during deposition through the boundary layer of a turbulent flow (Stow and Bowen, 1978). However, the more irregular interlayering and the reverse grading of some laminae suggest that the depositing currents showed some basic instability that was reflected in temporal and/or spatial variations in velocity, concentration, or another parameter. Coupled with this flow instability, excessively rapid deposition from essentially fine-grained flows may explain the very thick mud beds with barely perceptible lamination, and the extreme loading/convolution/contortion of some interlayered silt-mud units.

Our thin section study confirms the occurrence of microfaults, which can be related either to slumping (e.g., Sites 616 and 617 ) or to minor synsedimentary deforma- 


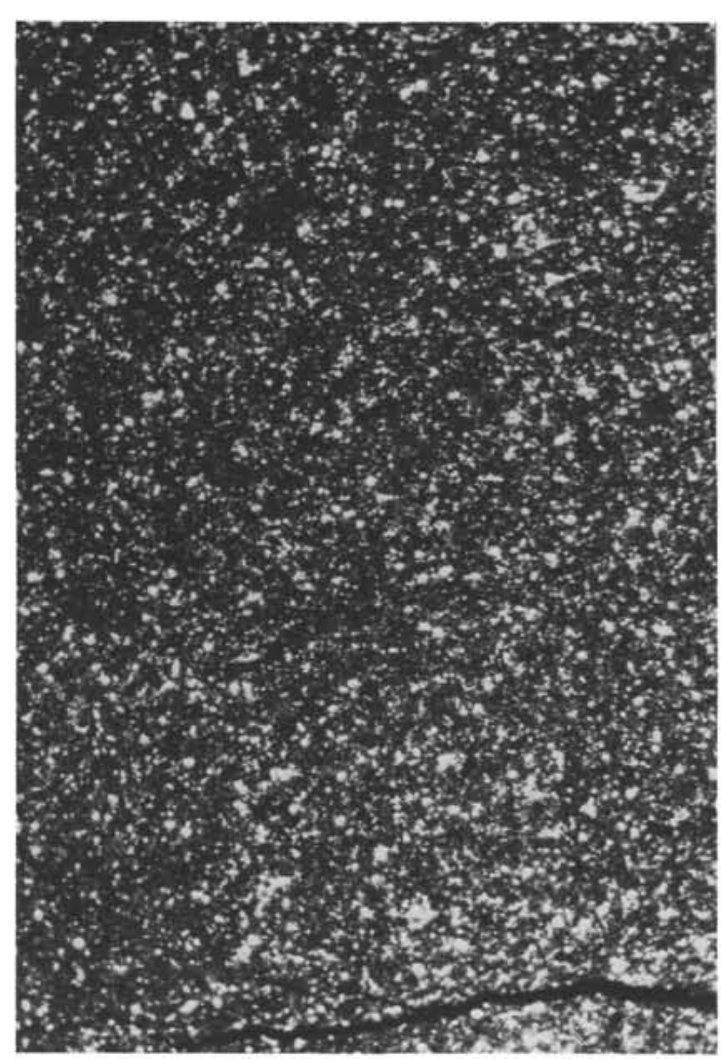

A

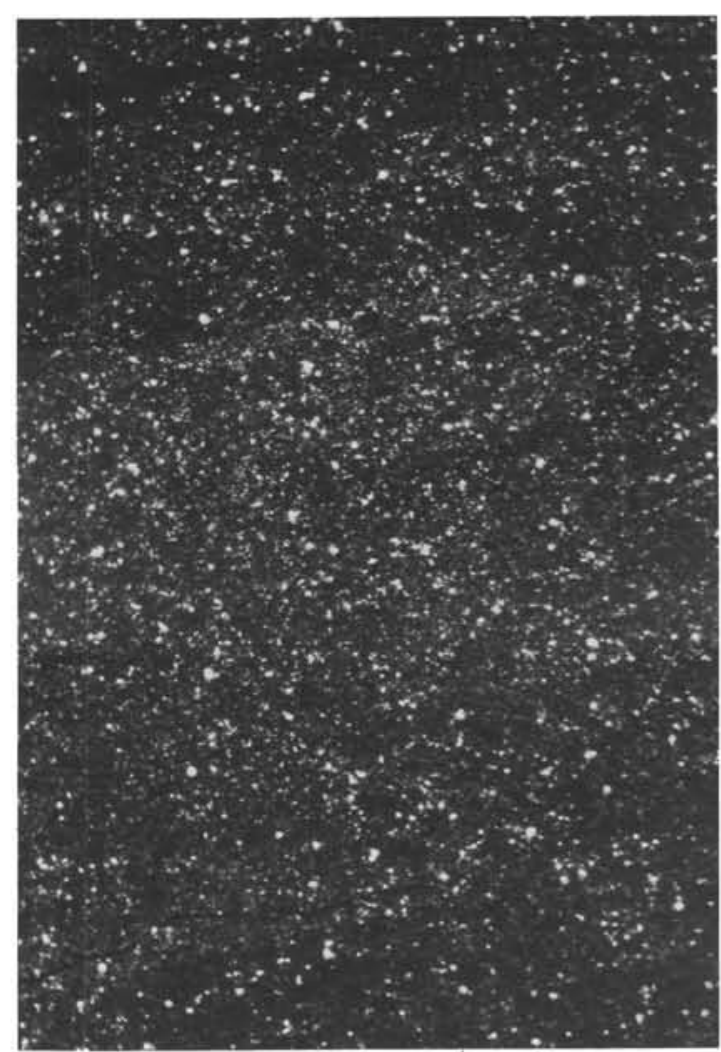

B

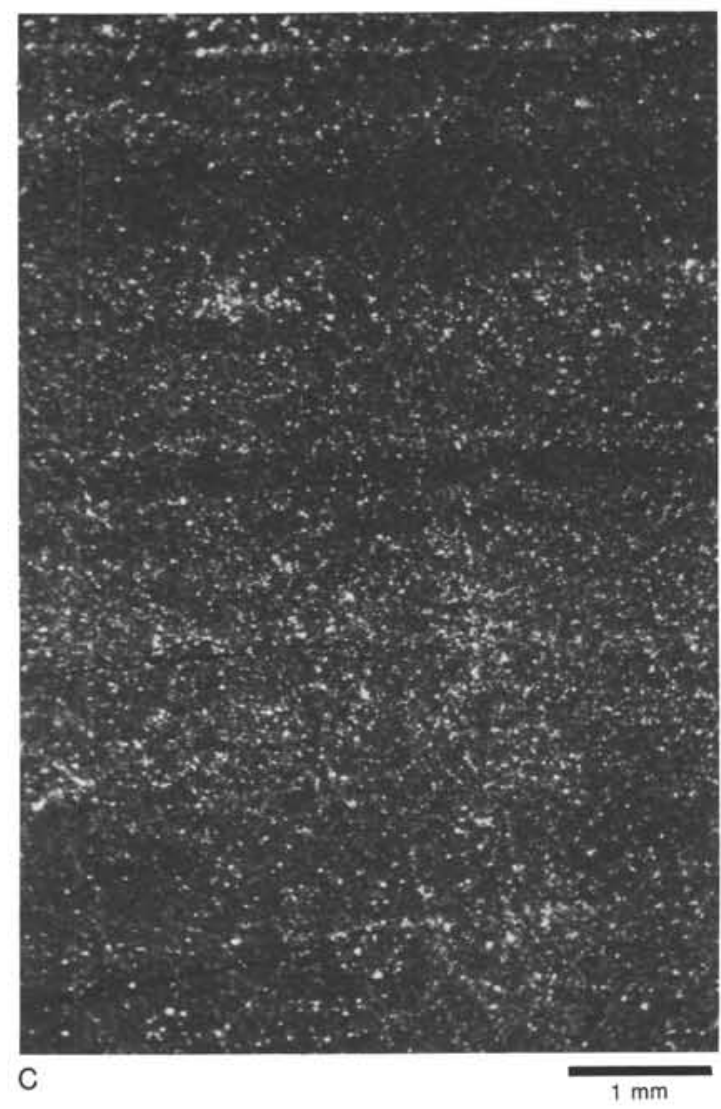

Figure 11. Microphotographs from subsamples of core Section 616-34-1: (A) 108-114 cm, (B) 53-59 cm, and (C) 9-15 cm from clay and mud facies. These subsamples were taken from a $120 \mathrm{~cm}$ homogeneous mud unit. However the photographs show an upward grain-size decrease concomitant with better sorting of the sediment into distinct silt and mud laminae. 
tion caused by very rapid deposition and sediment loading (e.g., Sites 615 and 617).

Three main questions arise from this study:

1. What are the criteria for defining the upper and lower limits of a single turbidite event? For example, repeated fluctuations in the flow behavior within a turbidity current can induce a complex succession of structures suggesting several turbidite events, or strong pulsations in one turbidity current.

2 . Is it possible to differentiate very fine-grained turbidites from the deposits of nepheloid layers? We cannot rule out the possibility that part of the almost structureless muds was deposited from semipermanent suspensions moving slowly downfan.

3. Can we define specific sedimentary structures that characterize distinct depositional settings on the fan? For example, the different sedimentary structures observed in this study must reflect the degree of confinement (channel vs. overbank) and the transport distance of the density flows from which they originated.

\section{ACKNOWLEDGMENTS}

H. Roberts and H. Nelson reviewed an earlier draft of this manuscript.

\section{REFERENCES}

Bouma, A. H., 1962. Sedimentology of Some Flysh Deposits: A Graphic Approach to Facies Interpretation. Amsterdam (Elsevier). , 1975. Sedimentary structures of Philippine Sea and Sea of Japan sediments, DSDP Leg 31. In Karig, D. E., Ingle, J. C. Jr., et al., Init. Repts. DSDP, 31: Washington (U.S. Govt. Printing Office), 471-488.

Bouma, A. H., Stelting, C. E., and Coleman, J. M., 1983/84. Mississippi Fan: internal structures and depositional processes. Geo-Mar. Lett., 3:147-153.

Chough, S. K., and Hesse, R., 1980. The northwest Atlantic MidOcean Channel of the Labrador Sea: III. Head spill vs. body spill deposits from turbidity currents on natural levees. J. Sediment. Petrol., 50:227-234.
Cremer, M., Droz, L., Normark, W. R., O'Connell, S., Pickering, K. T., et al., 1985. Thin section studies, Mississippi Fan. In Bouma, A. H., Normark, W. R., and Barnes, N. E. (Eds.), Submarine Fans and Related Turbidite Sequences. New York (Springer Verlag), pp. 319-324.

Hesse, R. and Chough, S. K., 1980. The northwest Atlantic Mid-Ocean Channel of the Labrador Sea: II. Deposition of parallel laminated levee-muds from the viscous sublayer of low density turbidity currents. Sedimentology, 27:697-711.

Kelts, K., and Arthur, M. A., 1981. Turbidites after ten years of deepsea drilling-wringing out the mop? Soc. Econ. Paleontol. Mineral., Spec. Publ., 32:91-127.

Lowe, D. R., 1982. Sediment gravity flows: II. Depositional models with special reference to the deposits of high-density turbidity currents. J. Sediment. Petrol., 52:280-297.

Nilsen, T. H., 1975. Turbidites, redbeds, sedimentary structures, and trace fossils observed in DSDP Leg 38 cores and the sedimentary history of the Norwegian-Greenland Sea. In Talwani, M., Udintsev, G., et al., Init. Repts. DSDP, 38: Washington (U.S. Govt. Printing Office), 259-288.

Piper, D. J. W., 1972. Turbidite origin of some laminated mudstones. Geol. Mag., 109:115-126.

1973. The sedimentology of silt turbidites from the Gulf of Alaska. In Kulm, L. D., von Hueue, R., et al., Init. Repts. DSDP, 18: Washington (U.S. Govt. Printing Office), 847-867.

, 1978. Turbidite muds and silts on deep-sea fans and abyssal plains. In Stanley, D. J., and Kelling, G., (Eds.), Sedimentation in Submarine Canyons, Fans and Trenches: Stroudsburg, PA. (Dowden, Hutchinson and Ross), pp. 163-176.

Stow, D. A. V., 1984. Turbidite facies, associations and sequences in the southeastern Angola basin. In Hay, W. W., Sibuet, J.-C., et al., Init. Repts. DSDP, 75: Washington (U.S. Govt. Printing Office), 785-799.

Stow, D. A. V., and Bowen, A. J., 1978. Origin of lamination in deepsea, fine-grained sediments. Nature, 274:324-328.

Stow, D. A. V., and Piper, D. J. W., 1984. Deep-water fine-grained sediments: facies models. In Stow, D. A. V., and Piper, D. J. W. (Eds.), Fine-Grained Sediments; Deep-Water Processes and Facies. Geol. Soc. London Spec. Publ., 15:611-645.

Stow, D. A. V., and Shanmugam, G., 1980. Sequence of structures in fine-grained turbidites: comparison of recent deep sea and ancient flysch sediment. Sediment. Geol., 25:23-42.

Date of Initial Receipt: 28 February 1985

Date of Acceptance: 1 August 1985 